\title{
Evaluation of the use of services provided by emergency care units in a Brazilian municipality
}

Avaliação da utilização dos serviços das unidades de pronto atendimento de um município brasileiro

Lubieska Rangel ZANON'

Luciane ZANIN' ${ }^{1}$

Flávia Martão FLÓRIO'

\section{ABSTRACT}

\section{Objective}

To characterize the users and to analyze the factors that determine their choice in using the emergency services.

\section{Methods}

The study was carried out in the two Emergency Care Units in Serra (Espirito Santo, Brazil). With regard to those users seeking the services of these Emergency Care Units, a trained interviewer approached 1 out of every 4 adults classified in the nursing consultation as not relevant to the Service ("false demand"), amounting to a total of 390 interviews. Using a validated questionnaire, the interview was conducted in accordance with the policies set out in the Health Service Action Plan. $80 \%$ of the demand was classified as not relevant.

\section{Results}

The "false demand" was chiefly composed of women (55.1\%), educated to a level between high school and incomplete higher education $(69.4 \%)$ and $14.6 \%$ were enrolled in private health plans. $78.5 \%$ had not previously sought any health service, in view of the ostensible guarantee of same-day care (43.1\%) or the difficulty in receiving care in the basic health units (37.9\%).

\section{Conclusion}

The majority of consultations performed in the Emergency Care Units should be resolved in basic healthcare facilities. The "false demand" is related to the reported difficulties the basic health units have in providing the necessary care and their ability to resolve the problem.

Indexing terms: Accessibility to health services. Emergency medical services. Unified Health System.

\section{RESUMO}

Objetivo

Caracterizar os usuários e analisar os fatores determinantes da escolha pela utilização dos serviços de urgência/emergência.

\section{Métodos}

A pesquisa foi desenvolvida nas duas unidades de pronto atendimento de Serra, Espírito Santo. Ao procurarem o serviço das Unidades de Pronto Atendimento, 1 a cada 4 usuários adultos, classificados na consulta da enfermagem como não pertinentes ao serviço, foi abordado e entrevistado baseado em um questionário validado. Para cada Unidade de Pronto Atendimento, foram entrevistadas 195 pessoas, totalizando 390 entrevistas.

\section{Resultados}

No período do estudo, $75 \%$ da demanda foi classificada como não pertinente, composta em sua maioria por mulheres (55,1\%), possuía escolaridade entre $2^{\circ}$ grau e superior incompleto $(69,4 \%)$ e $14,6 \%$ possuía plano de saúde. A maioria $(78,5 \%)$ não havia procurado nenhum serviço de saúde anteriormente, em vista da alegada garantia de atendimento no mesmo dia (43,1\%) ou da dificuldade de atendimento nas unidades básicas de saúde (37,9\%).

\section{Conclusão}

A maior parte dos atendimentos realizados nas Unidades de Pronto Atendimento deveria ser solucionado na atenção básica. A "falsa demanda" está relacionada ao relato de dificuldades no atendimento e na resolutividade das unidades básicas de saúde levando a população a procurar os serviços de urgência/emergência causando superlotação e problemas de rotinas dos mesmos.

Termos de indexação: Acesso aos Serviços de Saúde. Serviços Médicos de Emergência. Sistema Único de Saúde.

\footnotetext{
${ }^{1}$ Faculdade São Leopoldo Mandic, Programa de Pós-Graduação em Odontologia. Rua José Rocha Junqueira, 13, Swift, 13045-755, Campinas, SP, Brasil. Correspondência para / Correspondence to: FM FLÓRIO. E-mail: <flaviaflorio@yahoo.com>.
} 


\section{INTRODUCTION}

The problems experienced by the emergency services throughout Brazil are well documented and may be identified as the scarcity of human resources and materials, as well as overcrowding and the consequent mismatch between demand and supply, caused by the absorption of 'simple' cases that should be handled by other, less complex service units ${ }^{1-2}$. The excess demand points to the difficulties from which the population suffers with regard to access to health actions and services, even after the reforms to the unified health system in Brazil, known locally as the SUS, and the implementation of the process of municipalizing health and the Family Health Program (PSF), latterly referred to as the Family Health Strategy $(\mathrm{ESF})^{2}$.

The SUS guarantees full, universal and free access across the entire territory of Brazil, and healthcare is ordinated into levels of care where the Emergency Care Units (24 hr. UPA) correspond to an intermediate level of care . $^{3}$

The point of entry to the health system should preferably be basic healthcare ${ }^{4}$, made up of Basic Health Units (UBS) ${ }^{1,3,5-6}$ which, when they work properly, permit the majority of the population's health problems to be resolved, leading to a consequent reduction in lines at the mid- to high-complexity levels ${ }^{5}$. So the most common health problems should be resolved in these UBS, allowing the specialty day clinics and hospitals to get on with their real functions, resulting in greater user satisfaction and a more rational use of existing resources ${ }^{5-6}$.

At the present time, the basic system is in a situation of low response capacity, whether it be due to problems of infrastructure or the difficulty medical professionals are experiencing in performing their clinics effectively ${ }^{5}$. Generally speaking, basic services have been operating as emergency care units, focusing on symptomatic care, and thus being large-scale referrers, overloading the specialty medical services and the UPAs ${ }^{5}$.

In 2003, the Ministry Of Health launched its National Policy for Emergency Medical Care with the aim of structuring and organizing the emergency care system in the country $^{7-8}$ by seeking to integrate the emergency network ${ }^{9-10}$.

This network is composed of basic and family health units, specialty day-clinic services, UPAs and the Mobile Emergency Care Service. The UPAs are among the pre-hospital components in this network, being of intermediate complexity, falling between the Basic Health Units and the doors of the emergency hospitals ${ }^{3}$. Directive no. 1600 of July 7, 2011 restructured the emergency care system, revoking a directive issued in $2003^{10}$.

The health services should be organized so that primary care assumes the role of reorganizing the system into a conjoined, integrated network ${ }^{3,11}$. Given this perspective, the UPA's mission is that of attending with due competence to urgent and emergency cases, prioritizing care by way of acceptance via classification of risk, based on the identification of users that need immediate treatment, according to the potential health risks and complications ${ }^{3}$.

The classification of potential risk can be conducted using the Manchester Triage system ${ }^{12}$ which determines the clinical priority of the user, ensuring that the initial medical assistance takes place within an appropriate timeframe. The protocol classifies demand by color: blue, green, yellow, orange and red, this sequence arranging non-urgent patients who should be referred to health units without being attended to in the UPA (blue) or non-urgent, but who will be seen in the UPA (green) - through to urgent (yellow), very urgent (orange) and emergency cases (red) $)^{13}$.

Note that emergency units are being increasingly used by the population as a point of entry to the SUS2,5. It is thought that the reason for the demand in nonurgent situations is that, though overcrowded, impersonal and dealing with the main complaint, these health units also have at their disposal a wealth of resources, such as consultations, medication, nursing procedures, laboratory and radiological examinations, which satisfy the immediate needs of the population, thereby guaranteeing a greater possibility of serving as a point of entry to the health service system ${ }^{14}$.

Given this set of problems, it has become necessary to characterize the population being served, analyze the factors driving the use of public emergency units, present the view of the user concerning the use of the Unit and ascertain the process of the user's passage through the various services of the municipal health system, with the aim of making a contribution to health service reorganization policy, improving access and reducing waiting time for urgent/emergency services ${ }^{15}$.

Thus to investigate the relationship of medium complexity services with basic care, in respect of the demand for services, is an important factor in understanding the bottlenecks in a municipality's health system. As a result, the aim of this study is to characterize users, analyze the drivers of the choice to use the UPA's emergency services, in the municipality of Serra, in the Brazilian state of Espírito Santo. 


\section{METHODS}

This study was conducted in accordance with the principles determined by the Ministry of Health's National Health Council Resolution 196 of October 10, 1996, approved under protocol no. CAAE 23439114.6.0000.5374.

\section{Municipality and healthcare system data}

Serra is a mid-sized municipality in the Brazilian state of Espírito Santo, part of the Metropolitan Region of Greater Vitória, 17 miles from the state capital of Vitória. The municipality is composed of 5 districts: Serra-Capital, Calogi, Carapina, Nova Almeida and Queimado, and 124 neighborhoods. The population of Serra is 409,267 , mainly residents of the urban zone $(99.3 \%)$, making the municipality the second most populous in the state ${ }^{16}$.

The municipality's health system comprises 32 Basic Health Units (UBS), 7 Regional Health Units (URS), 2 Emergency Services Units (UPA), 1 Maternity hospital, 1 Serra Specialty Day Clinic (AMES), 1 Psychosocial Care Center for Alcohol and Drug Addicts (CAPS ad), 1 Psychosocial Care Center for Mental Disorders, 1 STD/AIDS and Viral Hepatitis Testing and Advice Center, 1 Ambulance Unit, 1 Mobile Heath Unit which services the municipality's rural zone, 1 Central Pharmacy, 1 Central Laboratory and 1 Environment Health Surveillance center. The professional staff consists of 510 doctors and 169 dentists. In an average month, 90,205 consultations are carried out of which 10,320 are specialized, 55,039 basic and 24,845 take place in the two emergency services centers and the maternity hospital. The number of examinations per month is $120,000^{12}$.

\section{Services network and population studied}

The study was carried out at the two Emergency Care Units in the municipality, situated in the districts of Serra-Capital and Carapina, which are responsible for servicing the population of the municipality as well as people from other cities and states. The average number of daily appointments is 400, both adults and children, in the Carapina UPA and 300 people in the Serra-Capital UPA, analysis and risk classification being carried out in accordance with the Manchester Triage system ${ }^{16}$.

The population base consisted of adults seeking medical assistance in the two UPAs of the municipality of Serra in the period from June 16 to June 30, 2014, between 8 a.m. and 5 p.m., excluding weekends. The sample to be interviewed, by UPA, was calculated taking into account the finite population of 10,500 adult appointments per month, a frequency of $70 \%$ of non-relevant treatments, according to data obtained from the review of the literature, confirmed in the pilot phase ${ }^{3,11}$, a confidence interval of $95 \%$ and margin of error of $10 \%$. A $20 \%$ rate of non-response was added to this value, hence a sample size of 195 participants per UPA.

\section{Pilot study}

Prior to the interview, a pilot study was conducted on 20 users, 10 per UPA, in which the researcher evaluated the interviewees' ability to use the questionnaire applied, thus ensuring that interview behavior did not influence or induce answers given by the user ${ }^{17}$.

In this stage, in order not to adversely impact the work of the nursing staff, it was necessary to adapt the study charts, in different colors, thereby permitting the sampling process to be systematized. Accordingly, in the risk classification interview, yellow charts were used for patients classified as relevant to the service and green charts for those not relevant. Each green chart was marked using a paper clip, in 4 different colors, and always in the same sequence.

\section{Sample selection}

On seeking the services of an UPA, users are first seen in reception where they fill out a form and wait for a consultation from a nurse for the classification of risk, observing the Manchester Triage system, those users classified with the colors blue and green being considered as non-relevant to the service.

The researcher would approach all users carrying green charts, marked with white paper clips, thereby ensuring that 1 in every 4 users classified as non-relevant to the service could participate in the study. In each UPA, this approach was maintained until the limit of 195 interviewees was reached, all of whom had to be residents of Serra, over 18 years old and with a cognitive ability that permitted them to participate in the interview.

\section{Interview stages}

The interview was conducted according to the principles described in the Health Services Action Plan ${ }^{18}$, observing the following stages: introduction, execution and conclusion. In the introduction phase, after the initial approach, explanation of the study and a check to verify their viability to participate in the study, the users were informed that it was not necessary to identify themselves and that the interview would last, on average, 10 minutes ${ }^{17}$. Once agreed, they were required to place their signature 
on the Free and Informed Consent Form. In the execution phase, information was supplied about the number of questions to be answered, emphasizing that there were no right or wrong answers and about the possibility of stopping the interview at any moment, when a question was not understood. The questions were put in the exact sequence proposed by the tool and none was skipped. At the end of the interview, the interviewer thanked the user for taking part.

\section{Data analysis}

The grouping of answers to the interviews conducted in the UPAs was used for the analysis. The data were analyzed descriptively, using the Excel for Windows software application.

\section{RESULTS}

\section{Demand profile}

Table 1 displays, for the period of the study and by day of the week, the number of adult appointments, ignoring dental appointments, by the social or pharmaceutical services. There was an average of 226 appointments every day, of which the vast majority were classified as not relevant to the service.

Table 1. Distribution of general practitioners' attended demand, according to the Manchester Protocol, day-of-the-week, during the study period. (Serra, ES, Brazil, 2014).

\begin{tabular}{|c|c|c|c|c|c|c|}
\hline Demand & Monday & Tuesday & Wednesday & Thursday & Friday & Mean \\
\hline Relevant & $47(19 \%)$ & $48(21 \%)$ & $45(21 \%)$ & $43(20 \%)$ & $44(19 \%)$ & $45(20 \%)$ \\
\hline Total & 243 & 228 & 216 & 215 & 227 & 226 \\
\hline
\end{tabular}

\section{User profile}

The average age of the users taking part in the study was $35.8( \pm 13.1)$. The majority of respondents were female $(55.1 \%)$, had a level of schooling between completed high school and incomplete higher education (69.4\%). Most of them were involved in remunerated work (73.9\%), 51.5\% of which were in possession of an employment card. It can also be seen that $14.6 \%$ of interviewees subscribed to a private health plan. Coverage of these plans for $3.6 \%$ of the volunteers is for all health-related expenses (Table 2).

Table 2. Users profiles of the emergency services. (Serra, ES, Brazil, 2014).

\begin{tabular}{|c|c|c|c|}
\hline \multirow[b]{2}{*}{ Variable } & \multirow[b]{2}{*}{ Category } & \multicolumn{2}{|c|}{ Frequency } \\
\hline & & Absolut & Relative \\
\hline Do you have health plans? & No & 327 & $83.80 \%$ \\
\hline \multirow[t]{6}{*}{ Which? } & Amil & 2 & $0.50 \%$ \\
\hline & Bradesco & 7 & $1.80 \%$ \\
\hline & PHS & 2 & $0.50 \%$ \\
\hline & Santa Mônica & 3 & $0.80 \%$ \\
\hline & UNIMED & 8 & $2.00 \%$ \\
\hline & Doesn't know / did not answer & 333 & $85.40 \%$ \\
\hline \multirow[t]{3}{*}{ Covers all expenses? } & Yes & 14 & $3.60 \%$ \\
\hline & No & 40 & $10.20 \%$ \\
\hline & Doesn't know / did not answer & 3 & $0.80 \%$ \\
\hline \multirow{3}{*}{ Schooling? } & Incomplete higher education & 139 & $35.60 \%$ \\
\hline & Complete higher education & 12 & $3.10 \%$ \\
\hline & Doesn't know / did not answer & 5 & $1.30 \%$ \\
\hline
\end{tabular}




\section{Access to health services}

Table 3 shows that the majority of interviewees $(60.5 \%)$ used public transport, buses, to get to their appointments. Note also that $78.5 \%$ of users had not sought any other health service prior to the visit to the
UPA. For the majority, the reason for this decision was to guarantee being seen the same day $(43.1 \%)$. Of the total number of volunteers seeking other health services before going to the UPA $(21.3 \%), 17.7 \%$ had attempted to resolve their health issues at a UBS that same day (13.3\%).

Table 3. Distribution of frequencies on the answers regarding the use of the emergency care units. (Serra, ES, Brazil, 2014).

\begin{tabular}{|c|c|c|c|}
\hline Variable & Category & \multicolumn{2}{|c|}{ Frequency } \\
\hline \multirow{4}{*}{ Reasons for choosing? } & Close to work & 42 & $10.80 \%$ \\
\hline & Had difficulty in being attended & 10 & $2.60 \%$ \\
\hline & Was referred to this service & 23 & $5.90 \%$ \\
\hline & Others & 67 & $17.20 \%$ \\
\hline Look for other health service prior to the visit to the UPA? & Did not answer & 1 & $0,26 \%$ \\
\hline \multirow[t]{2}{*}{ How many? } & One & 108 & $27.70 \%$ \\
\hline & $\begin{array}{l}\text { Did not look for the service or did not } \\
\text { answers }\end{array}$ & 282 & $72.30 \%$ \\
\hline Which services? & UBS & 69 & $17.70 \%$ \\
\hline \multirow{3}{*}{ First option ? } & Hospitals & 11 & $2.80 \%$ \\
\hline & Emergency Care Units & 111 & $28.50 \%$ \\
\hline & Did not answer & 30 & $7,70 \%$ \\
\hline \multirow[t]{2}{*}{ Use the UBS } & Yes & 201 & $51,50 \%$ \\
\hline & No & 189 & $48.50 \%$ \\
\hline \multirow[t]{3}{*}{ Difficulty of Attendance? } & Yes & 148 & $37.90 \%$ \\
\hline & No & 66 & $16.90 \%$ \\
\hline & Did not answer & 179 & $45,90 \%$ \\
\hline \multirow[t]{2}{*}{ Problems most commonly quoted } & Organizational or supply difficulties & 142 & $36.40 \%$ \\
\hline & Geographical obstacles & 11 & $2.80 \%$ \\
\hline
\end{tabular}

The majority of volunteers needing treatment for their health reported having sought a UBS as their first option (46.2\%). $51.5 \%$ of users stated they used the UBS close to home, though $37.9 \%$ stated they had difficulty in being attended to there. Among the problems most commonly quoted, organizational or supp ly difficulties were the most frequently mentioned $(36.4 \%)$.

\section{DISCUSSION}

The proposal to study users seeking UPAs, in situations not regarded as urgent or emergency, introduced as its line of analysis the accessibility to health services in a combination of factors of different dimensions permeated by the question of the health services care model, such as: geographical accessibility, organizational, sociocultural factors.

In the UPAs evaluated, the average number of general clinic appointments, taking into consideration only users aged 18 or above, was 226 people per day, of which around $80 \%$ were demands classified as not relevant to the emergency services, according to the data supplied by the institutions themselves at the end of each day. This low adaptation of demand agrees to 
other studies that evaluated the morbidity profile of patients in emergency cases $^{3,19-20}$. Long waiting times, lines and difficulty in getting emergency appointments are increasingly related to non-relevant demands on the service, that are the responsibility of basic healthcare ${ }^{19}$.

Taking sex and age into consideration, the distribution of users showed a higher frequency of women with an average age of 35 , a profile similar to other studies in the area ${ }^{3-4,20}$ which is attributed to the fact that fewer men seek health services even when it is a matter of urgency, particularly during business hours ${ }^{1}$.

The study was conducted on business days and during commercial hours, Mondays and Tuesdays seeing the highest number of appointments, corroborating another study which pointed to a similar tendency ${ }^{19}$. These periods correspond to the operating hours of the UBS that had to absorb this demand, however despite the idea that the SUS should bring medical care as close as possible to the population, taking the UBS out to the districts, $78 \%$ of those interviewed did not seek this service. Of the interviewees, $60 \%$ chose to travel longer distances, using public transport, and finding an UPA, indicating that the user's search for medical treatment does not, in principle, take geographical location of the heath units into account but rather the solutions the UPAs provide to meet their needs ${ }^{3,14,20}$.

The guarantee of same-day appointments was the reason claimed by $43 \%$ for seeking an UPA, in line with previous studies ${ }^{3,14}$. The culture of immediacy, in other words the promptness of obtaining a sameday appointment in the UPA, linked to problems with organizational accessibility in the UBS, represented by obstacles in the form of the organization of healthcare resources, the delay in obtaining an appointment, the lack of doctors, waiting times for treatment in the clinics and for carrying out laboratory examinations, reported by $36 \%$ of volunteers, prompts the population to head for the emergency units, even when simple solutions are required, thereby overloading the systems of medium complexity ${ }^{11,14-15,21}$.

The problem of increasing demand for emergency treatment, mainly characterized by the increase in false demand, is also found in other countries in Latin America and in Spain. In a systematic review conducted in Spain, a variation in false demand of between $25 \%$ and $79 \%$ was noted in the emergency services ${ }^{22}$. In Havana, in Cuba, a study conducted at emergency centers indicated that only $15 \%$ of the demand was characteristic of an emergency ${ }^{23}$.
In Mexico, one study quoted a figure of $33.64 \%$ true demand for emergency care in an emergency center in the state of Puebla ${ }^{24}$. Like Brazil, these countries are seeking to reduce this demand, using risk classification protocols and concur that it has an impact on the quality and timing of treatment of truly urgent cases $^{22-24}$.

The results of the present study confirm evidence that the population is reluctant to seek basic healthcare units for motives linked to the process of care provided. In this regard, health policies have been increasingly focusing on intensifying basic care, with the aim of taking health to the general public by means of health promotion and disease prevention measures, thereby reducing the need for actions to restore good health, and the implementation of the Family Health Strategy is considered to be the cornerstone of this process, as its design entails the ability to restructure basic care within this new concept.

Although the context of the development of basic care policies has an impact on the way health actions are generated, the use of services by the consumer takes place identically no matter whether in the UBS, completely or partially covered by the PSF, or in the UPAs ${ }^{2,5}$. This is possibly influenced by the traditional healthcare model centered on medical consultation and spontaneous demand ${ }^{5}$, as well as the potential fragility of the health system in terms of producing a linkage, and with an attitude that enables users to be listened to and welcomed, providing them with more appropriate responses ${ }^{9,14}$.

The results found in this study corroborate the evidence that it is necessary to reorganize the health services, as well as the urgent need for communication between administrators and the general public, so that their desires are, as a minimum, satisfied through basic healthcare, prompting this population to seek these services on a more frequent basis. The need is highlighted for efficient care in the basic health units and the population needs to be made aware of the real purpose of emergency services.

\section{CONCLUSION}

This study was carried out in a medium-sized city in Brazil, with characteristics similar to many municipalities in the country, and helps to clarify the profile of users and the reasons why they use the services of an UPA. The analysis of demand indicates an inappropriate use of the 
Service by a considerable proportion of its users, creating problems for the work routine. Given that the UPAs service spontaneous demand, this study confirmed what other researchers have been saying in respect of the functioning of this type of unit: that significant numbers of consultations should take place within the basic healthcare system and that a variety of factors drive the use of health services by the population, although the item most reported is the guarantee of receiving same-day medical consultation.

\section{REFERENCES}

1. Gomide MFS, Pinto IC, Figueiredo LA. Acessibilidade e demanda em uma Unidade de Pronto Atendimento: perspectiva do usuário. Acta Paul de Enfermagem. 2012;25(Espec 2):19-25. doi: 10.1590/S0103-21002012000900004

2. Simons DA, Monlleo IL, Simons AS, Araújo Jr. Adequação da demanda de crianças e adolescentes atendidos na Unidade de Emergência em Maceió, Alagoas, Brasil. Rev Bras Saúde Materno Infant. 2010 Jan-Mar;10(1):59-67. doi: 10.1590/ S1519-38292010000100006

3. Brasil. Ministério da Saúde. Secretária de Atenção à Saúde. Rede de atendimento 2010 [ciatdo 2013 Set 3]. Disponível em: $<$ http://brasil.gov.br/saude>

4. Brasil. Ministério da Saúde. Cartilha entendendo o SUS. Brasília: Ministério da Saúde; 2006 [citado 2015 Ago 5]. Disponível em: <http://portalsaude.saude.gov.br/images/pdf/2013/agosto/28/ cartilha-entendendo-o-sus-2007.pdf>

5. Pires MRGM. Oferta e demanda por média Complexidade / SUS. Relação com Atenção Básica. Ciênc Saúde Coletiva. 2010;15(suppl 1):1009-19. doi: 10.1590/S141381232010000700007

6. Pires MRGM, Gottems LBD, Cupertino TV, Leite LS, Vale $L R$, Castro MA, et al. A utilização de cuidados de saúde primários e serviços de emergência no SUS de Belo Horizonte: problemas de saúde, procedimentos e escolha de serviços. Saúde Soc. 2013;22(1):211-22. doi: 10.1590/S010412902013000100019

7. Brasil. Ministério da Saúde. Cadernos de Atenção Primária. Brasília: Ministério da Saúde; 2009 [citado 2015 Ago 5]. Disponível em: <http://dab.saude.gov.br/portaldab/biblioteca. php>.

8. Brasil. Ministério da Saúde. Portaria n. 1.863 de 29 de Setembro de 2003. Institui a Política Nacional de Atenção às Urgências. Brasília: Ministério da Saúde; 2003.

9. Medeiros AC, Almeida MS, Sabino MMFL. O processo de acolhimento com classificação de risco na Unidade de Pronto Sul. Col Gestão Saúde Pública. 2012;1:13-30.

10. Brasil. Ministério as Saúde. Portaria n. 1600 de 7 de julho de 2011. Reformula a Política Nacional de Atenção às Urgências e institui a Rede de Atenção às Urgências no Sistema Único de Saúde (SUS). Brasília: Ministério da Saúde; 2011.

\section{Collaborators}

LR ZANON contributed to the bibliographical review, was responsible for collecting and analyzing data and the composition of the article. LZANIN helped with the bibliographical review, analysis of data and composition of the article. FM FLÓRIO supervised the study, helped with the analysis of data and took part in the composition of the article.

11. Santos TVC, Penna CMM. Demandas cotidianas na atenção primária; o olhar de profissionais de saúde e usuários. Texto Contexto Enferm. 2013; 22(1):149-156. doi: 10.1590/S010407072013000100018

12. Serra (Cidade). Guia de serviços da saúde das Serra. Serra: Prefeitura da Serra; 2013 [citado 2015 Ago 5]. Disponível em: $<$ http://www.serra.es.gov.br/site/pagina/guia-de-servicos-desaude-da-prefeitura-da-serra>.

13. Forsman B, Forsgren S, Carlstrom ED. Nurses working with Manchester triage - The impact of experience on patient security. Austr Emerg Nursing J. 2012;15:100-7. doi: 10.1016/j. aenj.2012.02.001

14. Marques GQ, Lima MADS. Demandas de usuários a um serviço de pronto atendimento e seu acolhimento ao sistema de saúde. Rev Latino Am Enferm. 2007;15(1):13-9. doi: 10.1590/ S0104-11692007000100003

15. Oliveira MLF, Scoshi MJ. Determinantes da utilização dos serviços de urgência /emergência em Maringá (PR). Ciênc Cuidado Saúde. 2002;1(1):123-8. doi: 10.4025/ cienccuidsaude.v1i1.5666

16. Espírito Santo (Estado). Secretária de Planejamento Estratégico. Serra em números. 4a ed. Serra: Secretária de Planejamento Estratégico; 2011.

17. Bohn MLS, Lima MADS, Duro CLM, Abreu KP. Percepção de enfermeiros sobre utilização do protocolo do sistema de classificação de risco de Manchester. Cienc Cuid Saude. 2015;14(2):1004-10. doi: 10.4025/cienccuidsaude. v14i2.21359

18. Brasil. Ministério da Saúde. Caderno do Programa Nacional de Avaliação de Serviços de Saúde: edição 2004/2005. Brasília: Ministério da saúde; 2004 [citado 2013 Set 10]. Disponível em: <http://www.saude.sp.gov.br/resources/ses/perfil/gestor/ homepage/auditoria/manuais/pnass-programa_nacional_de_ avaliacao_de_servicos_de_saude.pdf $>$.

19. Oliveira GN, Silva MFN, Araujo IEM, Carvalho Filho MA. Perfil de uma população atendida em uma unidade de emergência referenciada. Rev Latino Am Enferm. 2011;19(3):548-6.

20. Simons DA, Monlleo IL, Simons AS, Araujo Junior JL. Adequação da demanda de crianças e adolescentes atendidos na unidade de emergência de Maceió, Alagoas, Brasil. Rev Bras Saúde Mater Infant. 2010;10(1):59-67. doi: 10.1590/S151938292010000100006 
21. Garcia VM, Reis RK. Perfil dos usuários atendidos em uma unidade não hospital de urgência. Rev Bras Enferm. 2014;67(2):261-7. doi: 10.5935/0034-7167.20140035

22. García MM. Estudio del triaje en un servicio de urgencias hospitalario. Rev Enferm CyL. 2013;5(1):42-9.

23. Rodriguez JP, Sanchez ID, Rodriguez RP, Acosta AS. "Filtro sanitario" en las urgencias médicas: un problema a reajustar. Rev Cubana Med. 2001;40(3):181-8.
24. Fajardo-Ortiz G, Ramírez-Fernánde FA. Utilización del servicio de urgencias en un hospital de especialidades. Cir Ciruj. 2000;68(4):164-8.

Received on: 9/10/2015

Final version resubmitted on: 22/12/2015

Approved on: 7/1/2016 